\title{
THE USE OF AUTHORIAL CORPORA BEYOND LINGUISTICS
}

\author{
RICHARD ZMĚLÍK \\ Faculty of Arts, Palacký University, Olomouc
}

\begin{abstract}
ZMĚLÍK, Richard: The Use of Authorial Corpora Beyond Linguistics. Journal of Linguistics, 2017, Vol. 68, No 2, pp. $404-414$.
\end{abstract}

\begin{abstract}
The study concentrates on the issue of quantitative and qualitative methods within the context of literary theory. It intends namely to present the concept of the literary corpus of Czech prose and define main parameters of the corpus. Besides the project of a specialized corpus, primarily intended for the use in the field of literary theory, the study deals with current stochastic and corpus methods applied by foreign scholars in analysis of literary prosaic texts. The study tries to incorporate the original project of Czech prose literary corpus in this contemporary context that represents one form of a recently flourishing discipline called Digital Humanities (Digital Literary Studies).
\end{abstract}

Keywords: Literary Studies, Digital Humanities, Literary Corpus, Thematic Analysis

\section{INTRODUCTION}

Electronic corpora of national languages recently form a natural and truly essential part of linguistic studies. Specifically, the Czech National Corpus has recently not only been constantly extended, but also improved as for its functioning, the instruments used to utilize the corpus data, and even the concept of structuration of the corpus itself. The usability of language corpora has its source not only in the storage capacity of contemporary electronic platforms but also in the relevant way of stratification of linguistic data and in the method of their analysis. The notion of representativeness [10] thus becomes one of important features of a modern corpus. This feature can be understood in several different ways. In case of the Czech National Corpus, the concept of representativeness is based on relative gender balance of various types of texts part of which is naturally formed by artistic literary texts. ${ }^{1}$

Even though it is certainly possible to utilize such (sub)corpora in literary-theoretical research it is necessary to realize that the conception of the corpora is motivated by other than literary-theoretical purposes and it is primarily meant for linguistic exploitation. In spite of the fact that in SYN 2015 the genre taxonomization of texts $^{2}$ is more elaborate than in older corpora, the usability of the corpora for serious literary-theoretical study is problematic; the main reason for that has already been mentioned: the essential conception standpoint is linguistic - that is why it, quite naturally, ignores purely literary-theoretical criteria. Since the need to utilize modern

${ }^{1}$ In the pre-corpus era, linguists used namely literary texts as sources of quantitative analyses, serving predominantly to linguistic purposes, not to the purposes of literary theory [11], [12].

${ }^{2}$ As for fiction, namely the division (segmentation) between narrative (prosaic) and nonnarrative (poetic) text has been implemented. Authors of the study presenting the new version of the corpus also emphasize that current tendencies prefer the use of smaller and specialized corpora. 
corpora in literary-theoretical research rises we intend to define elementary requirements and preconditions for a special conception of fiction corpora, or rather prose corpora, that will be effectively used mainly by literary theoreticians.

\section{Initial Conception of a Literary Corpus}

If we now proceed to primary arrangement of the literary corpus we may take into consideration following fundamental intentions. First of all, the corpus should reflect a developmental viewpoint, specified by temporal relations between different groups of texts (texts written by the same author, texts written by different authors). Intratextual and extra-textual markers for modelling and testing of particular phenomena should be available. Intra-textual markers will be related to the very analysis of the text matter (by analysis we mean primarily quantitative delimitation of thematic groups, entropy, lexical richness of texts, etc.). Extra-textual information, on the other hand, includes all specification data of the texts, such as data concerning authorship, gender phenomena, genres, location and time of origin, sequence of editions, etc.

A foundation from which a literary corpus can grow should be formed by corpora of smaller extent, primarily by authorial corpora that can be built independently but in accord with a predetermined strategy of building the corpus as a whole. (The final purpose of the corpus is to map the production of Czech prosaic literature from the $19^{\text {th }}$ century to present times.) At the level of authorial corpora that will form elementary structure units of the intended corpus it is possible to stick to the following preliminary scheme:

ELEMENTARY STRUCTURE UNIT OF A FICTION CORPUS

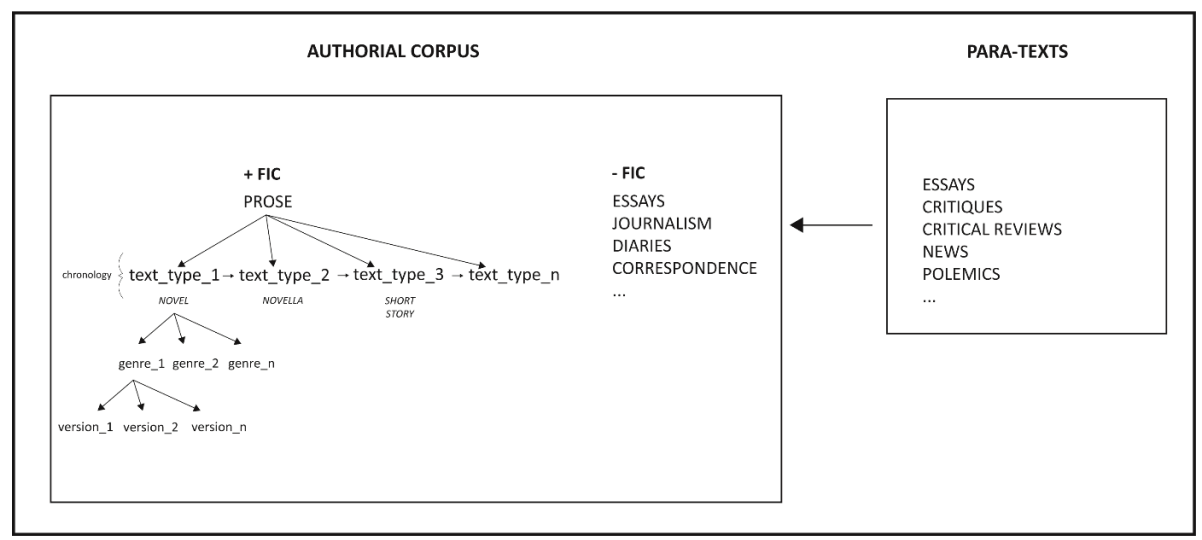

Fig. 1. A model of structuration of a partial authorial corpus serving as an elementary structure unit of the intended corpus of literary fiction

Each of authorial corpora will be divided in two main textual parts: fictional texts (prosaic, or possibly dramatic), and non-fictional texts. Special segmentation will pertain mainly prose that will be divided into individual genres and subgenres and subsequently to particular text variants. Para-texts, specified as to their type (review, critique...) and relation to a particular prosaic text, will form part of each au- 
thorial corpus. At this level of corpus building, a relatively sophisticated net will be formed within each segment of the corpus, connecting not only texts and para-texts but also individual literary texts. The net will enable corpus users to model particular literary texts in their relations to predefined chronological perspectives. We specifically mean the chronology defined according to the perspective of the first edition of each literary work and the chronology I accord with a subsequent, repeated edition (see Fig. 2).

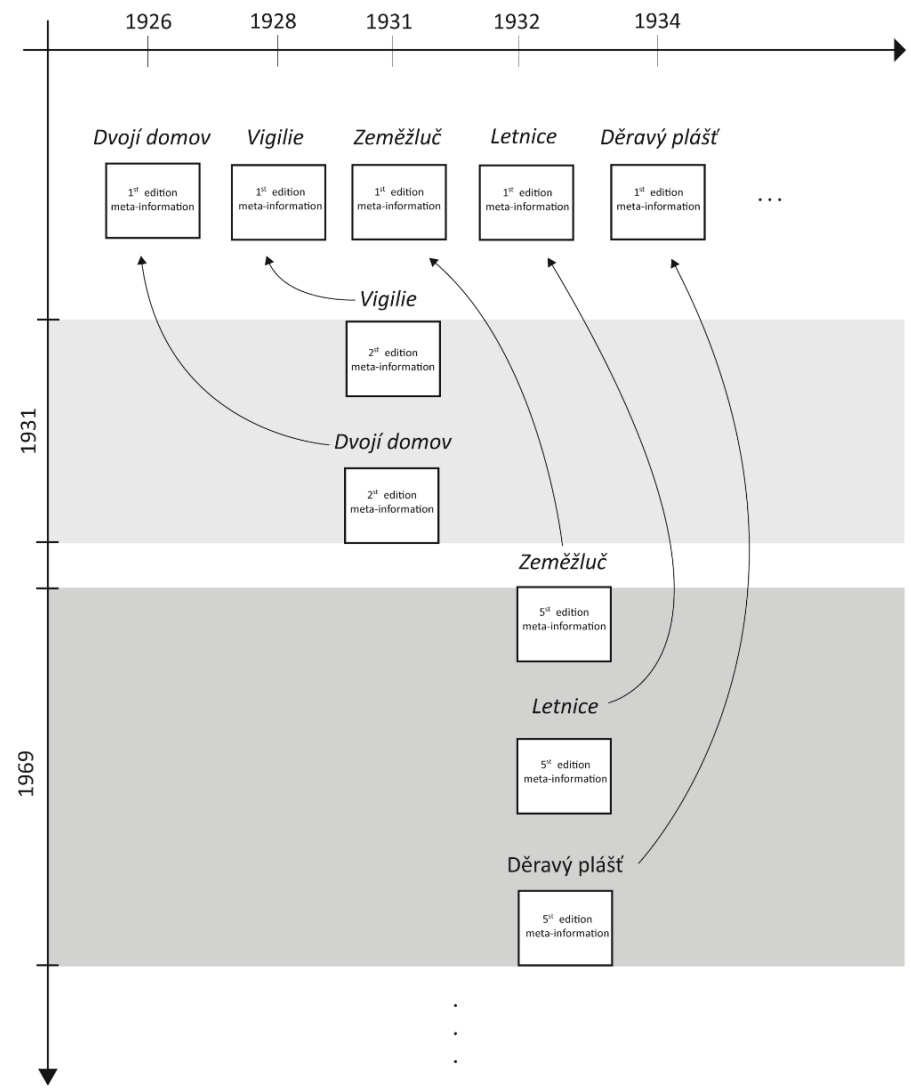

Fig. 2. The model of double chronology: first editions are marked on the horizontal axis, repeated editions on the vertical axis

Each text processed to become a part of the special literary corpus will be supplied with a set of metadata that can enable corpus users not only to find other ways of searching the corpus but also to analyse and model consistent with the criteria significant for literary history. Elementary data concerning the author and the text must be included in the meta-information, as well as other information pertaining location and date of a particular edition, number of copies, book format, etc. 


\begin{tabular}{|c|c|}
\hline $\begin{array}{l}\text { Meta-information } \\
\text { of artistic prose }\end{array}$ & $\begin{array}{l}\text { Meta-information } \\
\text { of para-texts }\end{array}$ \\
\hline $\begin{array}{l}\text { <main title of the work> } \\
\text { <partial title> } \\
\text { <autor> } \\
\text { <sex> } \\
\text { <year of the edition> } \\
\text { <location of the edition> } \\
\text { <editor> } \\
\text { <publisher> } \\
\text { <number of edition> } \\
\text { <number of pages of the whole text> } \\
\text { <number of pages of the partial text> } \\
\text { <number of copies> } \\
\text { <format of the book> } \\
\text { <genre> } \\
\text { <subgenre> } \\
\text { <note> }\end{array}$ & $\begin{array}{l}<\text { title of the text }> \\
<\text { title of the source }> \\
<\text { autor }> \\
<\text { sex }> \\
<\text { year of the edition }> \\
<\text { location of the edition }> \\
<\text { genre }> \\
<\text { in relation to the author }> \\
<\text { in relation to the book, text }> \\
<\text { note }>\end{array}$ \\
\hline
\end{tabular}

Fig. 3a. Fundamental meta-information types for a different type of texts

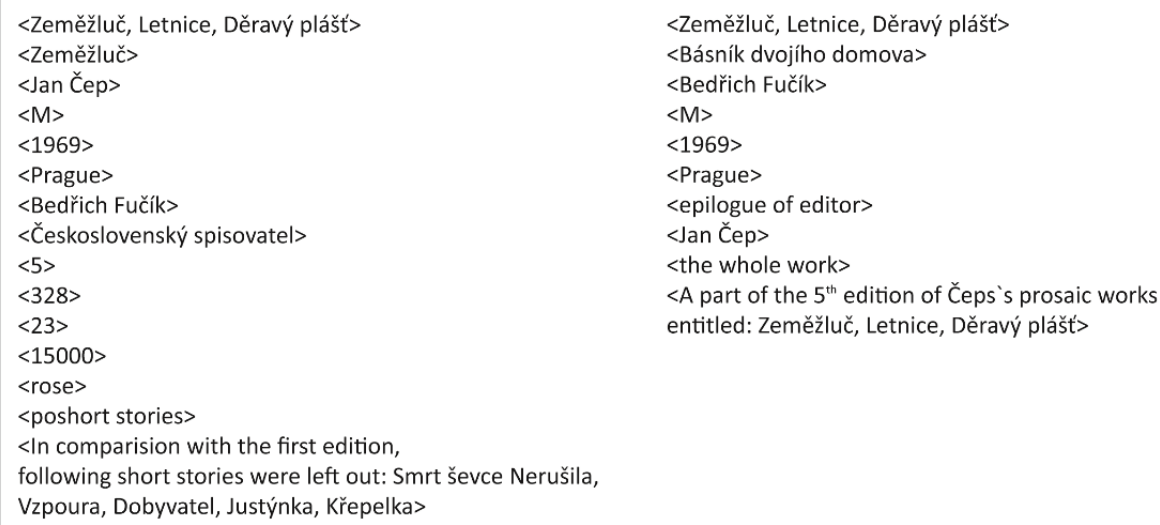

Fig. 3b. As an example we may state a complete edition of three short-story anthologies by Jan Čep, Zeměžluč, Letnice a Děravý plášt', in its edition from 1969, and a study written by Bedřich Fučík that supplements the edition.

The resulting model of the corpus will subsequently be open to numerous types of comparing and types of modelling. Corpus users will be able to compare partial texts of different authors as well as complete works or groups of texts defining literary schools, trends and tendencies. It will be possible to analyse even individual groups thanks to their inner structuration and differentiation. Importantly, comparisons will not have to be based exclusively on external criteria, i.e. on information supplied from literary-theoretical sources; corpus users will be able to test texts and works on the grounds of stochastic analyses and simultaneously observe and evaluate relations and bonds realized between individual sets of data. The above stated advancements will serve to systematic monitoring of developmental tendencies and more recent publishers' and editors' modifications. At the same time, on the quantitative level, it will be possible to model the course of reception of individual texts in 
newspapers and journals of the period (see Fig. 1), to monitor quantitative changes in the reception, and to compare thematic correlations between the texts and their critical reflections in the genre field of journalism.

\subsection{Thematic Analysis}

Thematic analysis is one of the significant functions of the intended corpus. Within the purview of quantitative-corpus approach, its methods can be divided in two main categories. The first category is based immediately on the stochastic principles that represent a central criterion of the analysis. Such methods fully rely on statistic algorithm applied on lexicon and as such they are fully quantitative.

In the Czech context, the method of so-called thematic concentration of text has attracted wider attention. The method uses division of lexicon in two main areas according to symptomatic occurrence of certain types of lexemes. In relation to frequency of occurrence, in each lexicon two areas can be separated: one area with prevailing synsemantic words, words that are found in higher frequency zones, and another area in which autosemantic words gradually dominate. For the method of measuring thematic concentration text, defining of so-called $h$-point, a point that statistically defines the border dividing the two areas, is crucial. ${ }^{3}$ Filtering of autosemantic words in the area for which occurrence of synsemantic words is typical (that is in the area above the $h$-point), symptomatic lexemes that reflect thematic orientation of the text are detected. In subsequent steps of thematic analysis it is possible to taxonomize these lexemes in semantic classes and create more general models of semantic groups the paradigms of which can be mutually compared [15]. ${ }^{4}$

Outside the Czech Republic, the research focused on thematic analysis of text currently also uses other methods. The study of Mathew L. Jokers [6] can serve as a typical example of such analytic methods, used in the context of literary-historical research. Jockers realizes that thematic analysis must be based on stochastic parameters different from those applied with so-called associative measures. ${ }^{5}$ If, as Jockers suggests, collocations or key words are not sufficient for a relevant determination of

${ }^{3}$ "The method of TC (thematic concentration) measuring is based on the character of frequency structure of the text, particularly on so-called $h$-point $[\ldots]$ and on the sequence and frequency of words signalizing the topic of the text above this point" [2, pp. 15-16]. On the other hand, certain misunderstanding can arise in the situation when no autosemantic word appears above the border line. In such occasion, it would certainly be misleading and wrong to suppose that the analysed text has no theme.

${ }^{4}$ In the Czech context, the method of thematic concentration of text is developer namely by Radek Čech [3].

5 "If our goal is to understand the narrative subjects and the recurrent themes and motifs that operate in the literary ecosystem then we must go beyond the study of individual n-grams, beyond the words, beyond the KWIC lists, and beyond even the collocates in order to capture what is at once more general and also more specific. Cultural memes and literary themes are not expressed in single words or even in single bigrams or trigrams. Themes are formed of bigger units and operate on a higher plane. If we may know the sense of a word by the company of words that surround it in a sentence, we may know a theme by the sentences, paragraphs, chapters, and even full books that express it. In short, simple word-to-word collocation and KWIC lists do not provide enough information to rise to the level of theme. What is needed in order to capture theme are collocations of collocations on a much larger scale" [6, p. 122]. 
thematic orientation of a text or a group of texts - namely because these qualities and their values are still overly determined by authorial style - it is necessary to develop an alternative quantitative procedure. As an alternative, Jockers suggests so-called latent Dirichlet allocation (LDA) which is able to cumulate thematically close lexemes in one paradigm. The LDA method of lexicon analysis surpasses collocations and KWIC since it can register even words that are very distant in the text (and undetectable by any available measurements of association) and include them in a common thematic set. ${ }^{6}$ Currently many researchers who apply quantitative methods namely in the field of literary history use thematic and stylometric models based on quantification of immanent structural features of texts and text groups. Examples of the use of such methods can be found for example in a collective monograph entitled Distant Readings: Topologies of German Culture in the Long Nineteenth Century (2014). ${ }^{7}$

From the methodological viewpoint, the approach based on a priori thematic tax-

${ }^{6}$ In his work, Jockers mentions two lexemes, stream(s) and Indians that appear in mutually distant positions in an analysed text (Thomas Mayne-Reid: The Scalp Hunters, 1851). The LDA analysis can include them in one thematic cluster [6, p. 127]. Jockers worked with a corpus of 3346 prosaic texts written in English. With the use of MALLET software (http://mallet.cs. umass.edu/) he defined (named) 500 thematic groups [19]. This is how Jockers describes the method: "MALLET output includes two derivative files: a file containing topic 'keys' and file containing the proportions of each topic found in each text, or each text segment in this case. The keys file is a simple matrix in which the first column of data contains a unique topic identifier, and a second column contains the top words assigned to the topic. [...] The second derivative file that MALLET produces provides data regarding the amount (proportion) of each topic found in each text segment. The modelling process assumes that every document is a 'mixture' of all the 500 possible topics in the corpus. Thus, each document is composed of some proportion of each of the 500 topics. Motivated by the work of the Veselovsky brothers [author means Alexander Nikolayevich Veselovsky, a Russian literary theoretician (1838-1906) - R. Z.] and their interest in studying literary evolution in terms of recurring motifs and national literatures, I began my analysis by plotting the mean proportions of every topic, in every year, separated first by nation, then by gender, and finally by nation and gender combined. Linking all of the thematic and topical data to the metadata facilitated the identification of thematic and topical patterns at the level of the corpus, at the level of the individual book, and across facets of time, gender, and nationality" [6, pp. 135-136].

${ }^{7}$ Title of the publication deliberately adverts to the book Distant Reading (2013) by Franco Moretti who significantly predefined current possibilities of application of quantitative methods in literary history. See also other Moretti's books in which the author deals not only with quantification but also with literary cartography [9]. The mentioned collective is dedicated to different aspects of quantitative study of literary texts of the $19^{\text {th }}$ century. While presenting the elementary characteristic of the aspects, editors of the publication emphasize the possibility of systematic analysis of a large amount of textual data as one of the main benefits of applying the quantitative-corpus approach in literary theory: "For the literary historian concerned with incorporating larger numbers of texts and viewing works in a broader social, industrial, even transnational context toward discovery of the past, however, close reading of texts simply does not suffice. It does not adequately answer questions about the production and circulation of books, taste information, or even necessarily about the relative position of texts in the literary field" [5, p. 9]. They stress out the opposition of the distant reading and close reading methods [5, pp. 8-9]. What makes the approach they apply really significant is the fact that no matter how well quantitative methods and algorithms can process vast quantities of data, no matter how well they can generate meaningful models according to predefined criteria they cannot fully substitute literary-theoretical interpretation. Nevertheless, theoretical interpretation has, owing to the mentioned methods, a functioning instrument for analysis at its disposal that shifts literary theory closer to exact scientific procedures. 
onomy, independent of analysed texts (external taxonomy), typologically represents another way how to recognize and analyse thematic level. In other words, in contrast to previous examples, we now have an initial paradigm at our disposal that represents a particular way of thematic taxonomization. It is a product of a corresponding individual lexical-semantic and lexicographic method and it has the same disadvantages as the method. To get a concrete idea, we suggest following advancement: Tezaurus jazyka českého: Slovník českých slov a frází souznačných, blizkých a príbuzných (2007), a thematically organized dictionary, can represent the external paradigm for texts written in the Czech language. This extensive lexicographic work of Aleš Klégr, inspired directly by Roget's ${ }^{9}$ Thesaurus of English words and Phrases, Classified and Arranged so as to Facilitate the Expression of Ideas and to Assist in Literary Composition (1852), can boast with its functional modification in relation to the current state of Czech lexicon and with division of the lexicon into individual thematic-semantic classes, sections, and sub-sections..$^{10} \mathrm{~A}$ thesaurus conceived in this way has the advantage of thematic (not alphabetical) taxonomization of the lexicon; the dictionary can thus be used as an initial paradigmatic filter during thematic stratification of texts. ${ }^{11}$ The process of such segmentation will be based on the functional interconnection of the thesaurus and an authorial dictionary and its components that will be lemmatized; also, each lemma will be endowed with a frequency indication for a particular part of the authorial (sub)corpus. Due to algorithmic assigning of lemmas and their frequencies in corresponding thematic groups and classes declared by the thesaurus ${ }^{12}$, each authorial (sub)corpus will acquire a frequency based, stratified model of thematic blocs, structured in accord with the parameters defined by the Thesaurus. Each of these partial models will be subsumed under a common authorial corpus, and, subsequently, under a pre-defined set, such as period of time, genre, gender, etc. (see chapter 2.2). ${ }^{13}$

${ }^{8}$ Aleš Klégr briefly defines the thesaurus as follows: "Meaning (notion) is the main principle of entry ordering; subsequently, the words that signify a particular notion are stated in a dictionary entry. Thus, the thesaurus functions as an onomasiologic handbook that translates the vocabulary of a language, its specific varieties (such as dialects), or a particular discipline in a way that signifies relations between words that belong to the same thematic or semantic areas (so-called semantic fields). In other words, the dictionary links of the same or similar (synonymic) meaning, may they be hyperonyms, hyponyms, or words on the same level" [8, p. 7].

${ }_{9}^{9}$ Peter Mark Roget (1779-1869); for elementary biographical data related to the thesaurus [7, pp. 65-66].

${ }^{10}$ Particularly, the Czech thesaurus is divided into six elementary thematic classes: abstract relations, space, matter, intellect, will, and emotions (with religion and morality). In total, the Czech thesaurus contains 885 entries that are subsequently assigned to particular sections and classes [8, pp. 16-21]. Naturally, it is not necessary to respect such taxonomization. Klégr himself added new entries (Science, Sports, Gods) to the original Roget's classification.

${ }^{11}$ Klégr mentions this potential use of the thematic thesaurus [8, pp. 9-10].

${ }^{12}$ Luckily for potential programmers, an electronic database, built by the team lead by prof. Klégr within the programme A computerized thesaurus of the Czech language, was finished before the publication of the thesaurus.

${ }^{13}$ Klégr mentions the decoding function of the thesaurus in relation to Julius Laffal dictionary A Concept Dictionary of English (1973), designed by the author "for purposes of automatized analysis of notional contents of texts" [8, p 74], particularly of spoken texts produced people suffering from mental diseases: "The dictionary also contains a demonstration analysis of a text entitled Declaration of Independent. The analysis revealed that notions belonging to four classes, 
On the other hand, such advancement also inevitably involves certain distortion since it is dependent on a particular conception of external paradigm, i.e. on a particular chosen form of the thesaurus. Even though Klégr notes that the original Roget's thesaurus was meant as a descriptive, not normative, dictionary $[8$, p. 9] he also admits that the English thesaurus has become a model for numerous lexicographic works of this type de facto "reflects its author's world view" [8, p. 8]. As for the methodological orientation of thematic analysis, we rather prefer a combination of both types of orientation: a priori stochastic and a priori paradigmatic. The research can finally be focused on multiple methodological aspects. First of all, it will aim at the methodological issues pertaining thematic study of lexicon, at the ways of defining thematic classes and groups, at realization of partial thesauri [7, pp. 69-77],[8, p. $10]$, such as a literary thesaurus of the $19^{\text {th }}$ century, and at realization of more extensive versions of the already existing thesaurus, etc. [8, p. 11]

Naturally, the initial version of the Thesaurus database will not include all lexemes that will appear in literary texts. ${ }^{14}$ Therefore, the analysis must necessarily be accompanied by systematic adding of new lexeme in the original database or by modification of the present thematic paradigm. ${ }^{15}$ Two main operations should thus become the basis of the whole process: selection and classification on one side, and incorporation of residual lexicon in the main database on the other hand; both operations must complement each other.

LEAD, LAW, GROUP, and MOTV, appear in the text most frequently [8, p 74]. František Čermák points out that electronic thesauri are called ontologies: "Besides systemization of gathered terms in a formalized system, production of ontologies is motivated by possibilities of easy computerized searching of the terms, of ontology-based classification, of the use of ontologies in the semantic web, etc." [4, p. 328].

${ }^{14}$ Specifically, autosemantic words will be excerpted, i.e. nouns, adjectives, verbs, and adverbs [4, p. 164].

${ }^{15}$ In relation to adopting the original Roget's conception of the thesaurus, Klégr mentions numerous modifications that influenced not only the extent of the excerpted lexicon, but also the way of taxonomization (many original categories and subcategories proposed by Roget had either to be reduced or extended [7, p. 70]. Analogically, even the thesaurus formed on the basis of excerption of literary texts could be modified functionally. After all, as František Čermák stresses, "there are many systems proposed for the thesaurus and there is no way how to asses them objectively. The questions, answered differently in individual systems, include for example questions pertaining (a) possible existence of one overall hierarchy, (b) the issue of a top notion, (c) the number of hierarchic levels, (d) the number of the very classes, or (e) the correlation of the proposed hierarchic taxonomy with intuitive perception on one side, and a scientific taxonomy on the other side (if such taxonomy, similar to the ones incorporated in natural sciences, actually exists) etc. [...] If we summarize what has been said so far it turns out that each author conceives his/her hierarchy differently in all its aspects (see above a-e) and that none of the authors applies a scientific taxonomy" $[4$, p. 323; 324]. 


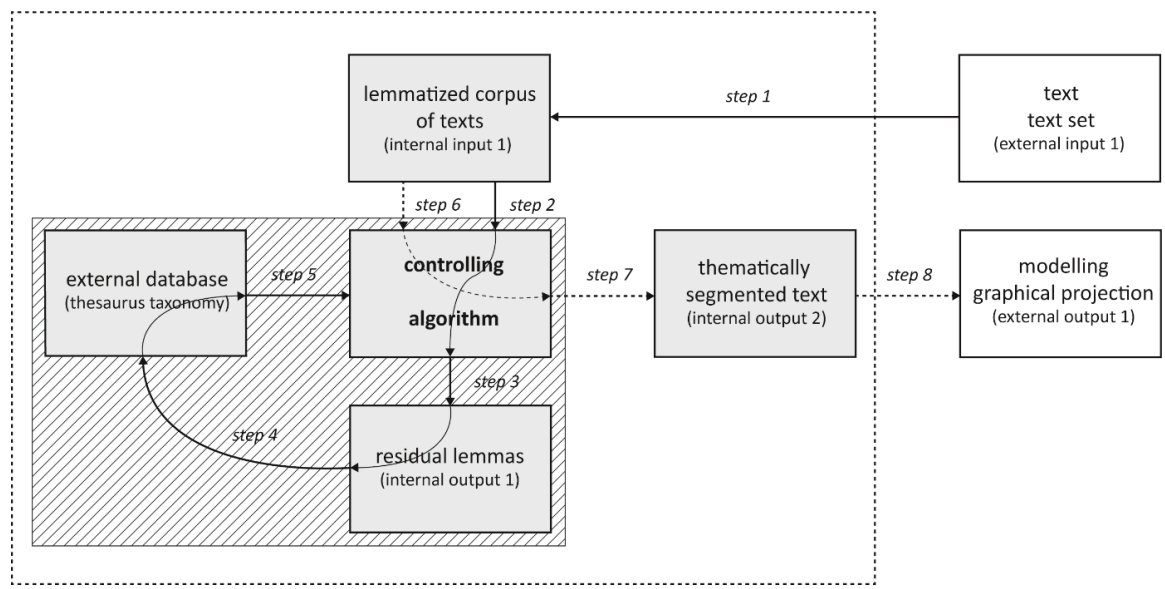

Fig. 4. The scheme of thematic analysis within the proposed literary corpus. At the level of external input 1, texts will be supplied in the electronic corpus database in the form intended for lemmatization. Internal input 2 includes lemmatized texts, recognized as particular text types or text sets, that will pass through the controlling algorithm; the thesaurus taxonomy will form an external component of the algorithm. This procedure will separate those lemmas that have not been recognized, and subsequently (step 4) the lemmas will be incorporated in the external database. The controlling algorithm will carry out another analysis with the output of a thematically segmented text in which to each thematic unit (group, class, etc.) the value of relative frequency will be allocated, specified on the basis of accumulation of corresponding lexemes. External output 3 is a graphical projection of this distribution, supplemented by optional functions in the extent of thematic layers (entry, section, class) and text groups, and by the function of graphical projection of frequency development of individual thematic classes etc.

Naturally, the results of the mentioned process can be used both by literary theoreticians - who will be able to register changes in distribution and stratification of thematic classes appearing in the course of a particular period of literary history and model them - and by linguists (see above). Linguistics will be provided not only with a constantly expanding thesaurus but also a large amount of material that can be used to study and analyse the issue of semantics and paradigmatics of the lexicon and for other purposes. ${ }^{16}$

\subsection{Meta-information as a Source of Literary-Theoretical Modelling}

Demands placed on a literary corpus must also include para-text information that should form an integral part of each lemmatized literary text (see Fig. 3.a). If in the context of current conception of building a synchronic corpus "explicit genre subclassification of fiction has been cancelled $[1$, p. 96] then in a literary corpus genre taxonomization must be preserved, namely with respect to the current literary-historical classification of texts. The corpus thus should be built in a way that serves the purposes of such research that would help to objectivize genre analysis and map or model transitional zones. Corpus-based research could incite more systematic and more variable study of genre categories and their specific features, initiate attempts

${ }^{16}$ It is not clear yet to what extent the still non-public database of Czech WordNet could be used in this process. 
at empirical delimitation of temporal genre centres, peripheries and transition zones, and namely register the dynamics of these changes.

A sufficiently representative part of the corpus will enable elementary statistic operations, based on pre-defined criteria stated at the level of meta-information, to be carried out. It will thus be possible to register genre and gender production of text in individual periods of time. Reception, i.e. critiques and critical reviews, matched to corresponding texts in the database, will become a significant indicator. We can realistically expect the literary corpus to enable composition of so-called reception waves, a phenomenon that is currently often studied by literary historians [13]. Observation not only of changes and developments in genre categories, but also of gender specifications or the degree to which individual publishing houses, locations of publication, etc. participated in the development, is very useful for both literary history and theory of literature. The mentioned findings will have to be combined with other indicators, namely with values brought by thematic analysis and analyses of lexical richness and entropy.

\section{CONCLUSION}

The conception of building a special literary corpus of Czech prose, as it was briefly presented above, may make modern electronic corpora accessible to the literary theorists who currently do not work with corpora ore use them scarcely. First of all, the proposed corpus would enable systematic research based on exact data and stochastic methods. It was Pavel Vašák ${ }^{17}$ who declared the use of such methods in literary theoretical research as reasonable and purposeful in the past. Currently, these tendencies are realized abroad; project such as Stanford Literary Lab [16] or .txtLAB [17] are partly focused on quantification of narrative segments in prosaic literary texts, etc.

As the project of Corpus of Czech verse [18] has suggested in the Czech context, specialized corpora using their own strategies and specific tools of statistic analysis appear as purposeful for literary theory. The literary corpus would finally be useful for other disciplines; namely with respect to the new conception of representativeness of the Czech language corpus it may also become a relevant instrument used by linguists. ${ }^{18}$

17 "General methodological use of mathematic - and, in a wider context, even of cybernetic and system - methods has currently become common. [...] It is therefore very advisable to use automatic computers that be of benefit to literary theory (and similarly to other humanist disciplines) at least in two respects:

1. they can gather data necessary for analysis and interpretation of literary works, may they be carried out either with mathematic or traditional methods. Formation of different concordance- or frequency-based dictionaries of significant authors, literary schools, movements, periods, generations, etc. would surely help literary theorists greatly.

2. Computers can also be used to look up and to gather bibliographic data" [14, pp. 52, 53].

18 "Corpus-based research currently changes its focus; from the effort to describe the language as a whole it shifts to the description of individual varieties or genres of the language (finding obtained through analysis of the data are not related to all texts but only to a specific group of texts that is actually represented by the data). This development partly results from the 
It has already been mentioned that specially processed authorial corpora should form the basis of the intended corpus; the building of these is exactly where the gradual systematic formation of the overall corpus should begin. Actually, testing of the proposed method of thematic analysis and its comparison with alternative methods applied to the lemmatized literary texts contained in the Czech National Corpus should be the very first step made towards the building of the Czech prose corpus in the future. Subsequently, two initial text centres, forming the basis for building of the corpus, will be founded - the first one situated to the $19^{\text {th }}$ century, the other one to the $20^{\text {th }}$ century. ${ }^{19}$ To build such a corpus, much time and close cooperation with literary theorists, linguists and programmers will be required.

\section{References}

[1] Cvrček, V., Čermáková, A., and Křen, M. (2016). A new design of synchronic corpora of writen Czech. Slovo a slovesnost, 77(2):83-101.

[2] Čech, R., Popescu, I., and Altmann, G. (2014). Metody kvantitativní analýzy (nejen) básnických textů. Palacky University, Olomouc.

[3] Čech, R. (2016). Tematická koncentrace textu v češtině. Institute of Formal and Applied Linguistics, Prague.

[4] Čermák, F. (2010). Lexikon a sémantika. Nakladatelství Lidové noviny, Prague.

[5] Erlin, M. and Tatlock L. (2014). Distant Readings: Topologies of German Culture in the Long Nineteen Century. Camden House, Rochester - New York.

[6] Jockers, M. L. (2013). Macroanalysis. Digital Methods and Literary History. University of Illinois Press, Illinois.

[7] Klégr, A. (2000). Rogetův Thesaurus a onomaziologická lexikografie. Časopis pro moderni filologii, 82(2):65-84.

[8] Klégr, A. (2007). Tezaurus jazyka českého: Slovník českých slov a frází souznačných, blizkých a príbuzných. Nakladatelství Lidové noviny, Prague.

[9] Moreti, F. (2014). Grafy, mapy, stromy: Abstraktni modely literární historie. Karolinum, Prague.

[10] Šulc, M. (2001). Tematická reprezentativnost korpusů. Slovo a slovesnost, 62(1):53-61.

[11] Těšitelová, M. (1948). Frekvence slov a tvarů ve spise ,Život a dílo skladatele Foltýna“ od Karla Čapka. Naše ř rě́, 32(9):297-307.

[12] Těšitelová, M. (1955). Poznámky ke slovní zásobě v románě Karla Čapka ,Život a dílo skladatele Foltýna'. Naše ř ě́, 38(9):297-307.

[13] Tureček, D. (2012). Synopticko-pulzační model českého literárního romantična. In České literární romantično: synopticko-pulzačni model kulturního jevu, pages 92-142, Host, Brno, Czech Republic.

[14] Vašák, P. (1980). Metody určování autorství. Academia, Prague.

[15] Změlík, R. (2015). Kvantitativně-korpusová analýzy a literární věda. Model a realizace autorského korpusu a slovniku Jana Čepa v kontextu zahranični a české autorské lexikografie. Palacký University, Olomouc.

[16] Stanford Literary Lab. Accessible at: https://litlab.stanford.edu/ .

[17] .txtLAB. Accessible at: https: / / txtlab.org/ .

[18] Korpus českého verše. Accessible at: http://versologie.cz/kcv.html.

[19] Jockers, M. L. 500 Themes from a corpus of 19th-Century Fiction. Accessible at: http: / / www . matthewjockers.net/macroanalysisbook/macro-themes/.

realization of the fact that a description at the level of the whole language would necessarily equalize the mutual dissimilarity of individual texts" [1, p. 92].

${ }^{19}$ As for the $19^{\text {th }}$ century, the work will begin with building of authorial corporal of members of individual movements and schools (authors gathered around the almanacs and journals Máj, Ruch, Lumir, etc.). 